\title{
Nauplii production of white shrimp, Litopenaeus vannamei (Decapoda: Penaeidae), on-board of commercial trawlers
}

\author{
Carlos E. Medina-Reyna ${ }^{1}$, Miguel H. Beltrán-González ${ }^{1}$ and Hector T. Salinas-Orta ${ }^{2}$ \\ 1 Instituto de Industrias. Universidad del Mar. Apdo. Postal. 47, Puerto Angel, Oaxaca, 70902 México. Fax (958) 43049. \\ Correo electrónico: peneion@angel.umar.mx.. \\ 2 Centro Regional de Investigaciones Pesqueras. Instituto Nacional de la Pesca. Av. Prolong. Ote. de Playa Abierta. Col. \\ San Juan. Salina Cruz, Oaxaca. México.
}

Received 28- VIII-1998. Corrected 26-III-1999 Accepted 16-IV-1999.

\begin{abstract}
Resumen: Los laboratorios no han logrado producir suficientes nauplios de buena calidad por lo que sigue siendo necesario recolectar hembras maduras en alta mar. Sin embargo, no siempre se recolectan hembras en la condición inseminada. En este estudio, se evaluó la recolecta de hembras y producción de nauplios abordo de un barco camaronero durante un viaje comercial como una alternativa para el larvicultivo de Litopenaeus vanname $i$ en el Golfo de Tehuantepec. Se efectuaron arrastres en la tarde hasta el anochecer. El mejor tiempo de arrastre fue de 20 min y produjo una captura media de $37 \pm 8$ camarones adultos con una sobrevivencia de $72 \pm$ $3 \%$. Se observaron desoves desde las 11:00 PM hasta las 02:00 AM, con un máximo a las 12:00 PM. Se siguieron 14 desoves en cinco días, durante los cuales se produjeron $2.2 \times 106$ nauplios con una tasa media de fertilidad y de eclosión de 83 y $75 \%$, respectivamente. Este trabajo presenta una técnica que puede proveer de simientes para el larvicultivo a partir de los productos reproductivos de camarones capturados por la flota camaronera comercial.
\end{abstract}

Key words: Nauplii, Litopenaeus vannamei, Sourcing, Larviculture

The Mexican Pacific shrimp fishery is among the most important fisheries in LatinAmerica (Magallón-Barajas 1987) and the Mexican shrimp culture production ranks second in the continent. Oceanic fishing season lasts from September to March. In these months, sexual maturity is reached and usually commercial shrimp boats trawl on ripe shrimp sub-populations, as in the Gulf of Tehuantepec, where reproduction occurs year-round. This practice decreases the reproductive output potential and leads to slow stock depletion (Salinas-Orta, pers. obs.). Reproductive output can be saved if commercial shrimpers recover a minimum amount of females discarded on its decks and spawned later under known rearing techniques. In this way, eggs can hatch and naupliar stages can survive in small-scale hatcheries located on the coast. From this point of view, small-scale hatcheries could circumvent the search for ready-to spawn females (Bray et al. 1982, Bray and Lawrence 1992). None of the many attempts to produce nauplii onboard commercial shrimp boats has reported successful trials (Beltrán-Félix 1987). Failure reflects ignorance of reproductive behavior under stress and the lack of equipment adapted to the conditions at sea. This study aims to assess the spawning and hatching potential of white shrimp Litopenaeus vannamei on-board a shrimp trawler equipped with seawater treatment and aeration systems during a commercial cruise in the Gulf of Tehuantepec. 
The study was carried out in the inner Gulf of Tehuantepec $\left(14^{\circ} 50^{\prime}-16^{\circ} \mathrm{N}, 92^{\circ}-96^{\circ} 40^{\prime}\right.$ W) between August 14 and 28, 1994, the onset of maximum reproduction in this area. A commercial shrimp trawler equipped with 25.5 $\mathrm{m}$ wide double-rigged nets with $5 \mathrm{~cm}$ mesh (Type Phantom) and a 365 HP engine was used. Five 400-1 square plastic tanks covered by PVC canvass were arranged on the upper deck $\left(8 \mathrm{~m}^{2}\right)$ for nauplii rearing. Three $400-1$ square plastic tanks were placed on the main deck as female conditioning tanks. Seawater was pumped directly from the ocean and passed though a 5- $\mu \mathrm{m}$ mechanical filter, and an activated carbon and UV filter. Air was supplied through fine pore diffusers from a $1 / 2$ HP blower. During the experiments, the seawater was $28-32{ }^{\circ} \mathrm{C}$ and 34 ppt. Water renewal in tanks was done twice daily, when pertinent.

Trawlings at depths ranging from 16 to 25 $m$ were made every day after sunset (17:0020:00), as recommended by Bray and Lawrence (1984). When a fishing ground with abundant adult shrimps was found (20-30 kg per hour of trawling), five consecutive trawls lasting 10 to $40 \mathrm{~min}$ were made during 5 days $(\mathrm{N}=20)$ to assess catching rate and survival after one hour of trawling, since these times do not produce severe injuries to shrimps (Beltrán-Félix 1987). According to Bray and Lawrence (1984), females with the full spermatophore attached on the thelycum or mated females (MF) with body weights ranging from 35 to $45 \mathrm{~g}$ were segregated during five consecutive days of cruising, counted, and then confined in conditioning tanks. After one hour, twenty randomly selected MF from 20 min trawling time were contained in spawning tanks on the upper deck, to evaluate the time of spawning.

When the technique of MF rearing was evaluated, egg and nauplii rearings were done similar to Wyban and Sweeney (1991) and Treece and Fox (1993). Spawnings with fertility rate (the proportion of normal eggs related to the total egg produced by each MF) higher than $80 \%$ were followed to naupliar stages ( $\mathrm{N}=14)$. Development of eggs and nauplii was checked hourly and daily with a disecting microscope, respectively, using criteria presented by Treece and Fox (1993).

Triplicate confinement trials were made to assess the survival of females transported at different densities in 400-1 tanks (using the equipment described above) during 24 and 48 $\mathrm{hr}$ navigation periods. Confinement tests were designed to evaluate the followings densities, usually used in sourcing: High (145 shrimps $/ \mathrm{m}^{2}$ ), Medium ( $127 \mathrm{shrimps} / \mathrm{m}^{2}$ ) and Low (91 shrimps $/ \mathrm{m}^{2}$ ).

The trawling times of shrimping nets towed in the present study produced a mean catch ranging from $23.8 \pm 8$ to $101 \pm 17$ adult shrimps per trawling. The highest catch was 40 min and the smallest was $10 \mathrm{~min}$. The mean survival decreased as trawling time increased; 10 and 20 min trawls produced the highest survival (Fig. 1). Mated females (MF) represented $40 \%$ of the individual catch, therefore, minimum amounts of MF needed for spawning were achieved. Therefore, $20 \mathrm{~min}$ trawlings were carried out to source mated females for successive experiments.

Mated females spawned from 10:00 PM until 03:00 AM, with a peak at 12:00 PM. In fact, $50 \%$ of the MF spawned during midnight, from 11:00 PM to 02:00 AM (Fig. 2). Due to spawning time, special care during this interval was given to optimize the nauplii production.

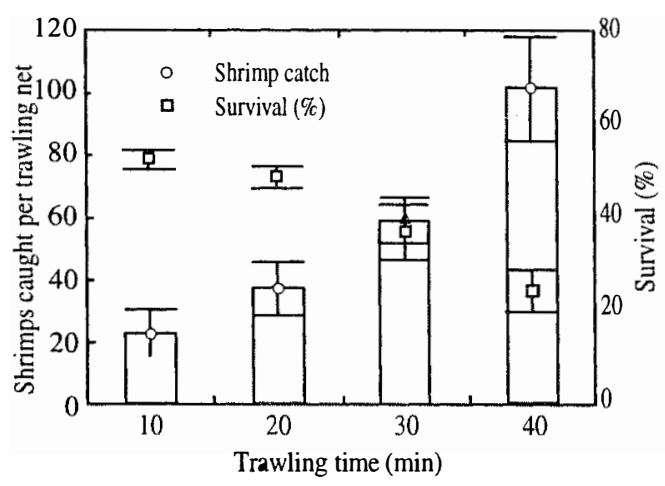

Fig. 1. Shrimp catch per trawling time and the survival of shrimps caught in each trawling time. Values are means \pm standard deviation (SD). 


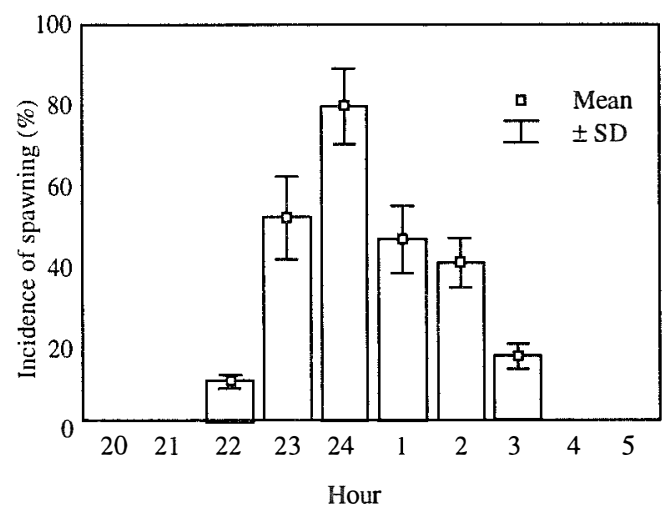

Fig. 2. Incidence time of spawnings of mated shrimp females caught in the Gulf of Tahuantepec. Values are means \pm SD.

A total of $2.2 \times 106$ nauplii were produced from females naturally mated $(\mathrm{N}=14)$ during four days of effective commercial fishing. Mean fertility rate of MF varied from $75 \pm 5$ to $87 \pm 7 \%$. Mean egg production ranged from $122 \pm 26$ to $244 \pm 40 \times 103$ eggs per spawn. Mean hatch rate varied from $61 \pm 11$ to $90 \pm 5$ $\%$, with a mean yield ranging from 83000 to 189000 healthy nauplii per spawn (Table 1). Ashmore (1988), Wyban and Sweeney (1991), Bray \& Lawrence (1992) and Robertson et al. (1993), under controlled conditions on the mainland, reported lower values: their mean fertility rate for $L$. vannamei varied from 40 to $70 \%$ and mean hatching rates ranged from 32 to 66 . Differences are probably caused by age, eyestalk ablation, nutritional status, genetic performance and enviromental conditions (Bray \& Lawrence 1992). Offshore spawning under the condition of this satisfies nauplii production needs for a small-scale hatchery. However, interannual variations of MF abundance must be monitored regularly to estimate how many MF could be caught using this approach.

Mature female transport is a difficult task for larviculture operations. High mortality can occur due to stress caused by trawling and confinement (Beltrán-Félix 1987). Low density confinement trials (91 shrimps per $\mathrm{m} 2$ ) during transport on a shrimp trawler produced highest survival in $24 \mathrm{hr}$. Survival at $48 \mathrm{hr}$ of transport at this density yield no further mortality (Tukey's HSD tests $p<.05$ ). Since the nearest ports are $24 \mathrm{hr}$ from the main spawning ground, low and medium density confinements are adequate.

This study shows the great potential of spawning mated shrimp females on-board of shrimp trawlers during commercial operations. Nauplii production is a reliable and alternative source on-board. The possibility of recovering wild reproductive outputs in places where fertilized products are continuously discarded during shrimping season in tropical waters represents a valuable resource for the shrimp larviculture.

Secretaría de Pesca (SEPESCA-México) authorized Permiso de Pesca de Fomento No. 1998 granted to the first author. Oswaldo Morales, Alonso Medina, and crew of FV Suriano XV provided technical assistance during cruise. Anonymous reviewers improved the English version.

\section{TABLE 1}

Mean statistics ( $\pm \mathrm{SD}$ ) for spawns of white shrimp Litopenaeus vannamei on-board of commercial shrimp trawler in the Gulf of Tehuantepec.

$\begin{array}{lccccc}\text { Date } & \begin{array}{c}\text { No. of } \\ \text { spawned } \\ \text { females }\end{array} & \begin{array}{c}\text { Mean } \\ \text { fertility } \\ \text { rate }(\%)\end{array} & \begin{array}{c}\text { Mean egg } \\ \text { production } \\ \left(10^{3} \text { egg/spawn }\right)\end{array} & \begin{array}{c}\text { Mean larval production } \\ \left(10^{3} \text { nauplii/spawn }\right)\end{array} & \begin{array}{c}\text { Mean } \\ \text { Hatching rate (\%) }\end{array} \\ \text { 19-VIII-94 } & 3 & 75 \pm 5 & 135 \pm 22 & 83 \pm 28 & 61 \pm 11 \\ \text { 20-VIII-94 } & 4 & 87.1 \pm 7 & 243.8 \pm 40 & 189.0 \pm 55 & 76 \pm 8 \\ \text { 21-VIII-94 } & 3 & 83.7 \pm 3 & 121.5 \pm 26 & 109.4 \pm 25 & 90 \pm 5 \\ \text { 22-VIII-94 } & 4 & 86 \pm 9 & 197 \pm 11 & 139 \pm 10 & 73 \pm 4\end{array}$




\section{REFERENCES}

Ashmore, S. B. 1988. Nauplii production results from a commercial Penaeus vannamei maturation facility in Hawaii (Abstract). J. World Aquaculture Soc. 19:15A.

Beltrán-Félix, J. L. 1987. Captura y desove de camarón Penaeus vannamei Boone y Penaeus stylirostris Stimpson. Cien. Mar (Méx) 10:10-16

Bray, W. A., G. W. Chamberlain \& A. L. Lawrence.1982. Increased larval production of Penaeus setiferus by artificial insemination during sourcing cruises. J. World Mariculture Soc. 13:123-133.

Bray, W. A. \& A. L. Lawrence. 1984. Sourcing Penaeus setiferus: A summary of larval production, incidence of capture of mated females, and mating incidence by time of day on research cruises 1981-1982. J. World Mariculture Soc. 15:11-28.

Bray, W. A. \& A. L. Lawrence. 1992. Reproduction of Penaeus species in captivity, p. 93-170 In A. W. Fast
\& L. J. Lester (eds). Marine shrimp culture: Principles and practices. Elsevier. Amsterdam, the Netherlands.

Magallón-Barajas, F. J. 1987. The Pacific shrimp fishery of Mexico. CalCOFI Rep. 28:45-52.

Robertson, L., B. Bray, T. Samocha \& A. L. Lawrence. 1993. Reproduction of penaeid shrimp: an operations guide, p. 107-132. In J. P. Mcvey (ed). CRC Handbook of mariculture Vol. I. Crustacean Aquaculture. CRC, Boca Raton, Florida.

Treece, G. D. \& J. M. Fox. 1993. Design, operation and training manual for an intensive culture shrimp hatchery (with emphasis on Penaeus monodon and Penaeus vannamei). Texas A\&M University Sea Grant Coll. Prog., Galveston, Texas.

Wyban, J. A. \& J. N. Sweeney 1991. Intensive Shrimp Production Technology. The Oceanic Instit. Shrimp Manual. The Oceanic Institute. Honolulu, Hawaii. $156 \mathrm{p}$. 